\title{
X-linked Hyper IgM (HIGMI) in an African kindred: the first report from South Africa
}

\author{
Sandra Pienaar ${ }^{1}$, Brian S Eley*1, Jane Hughes ${ }^{1}$ and Howard E Henderson ${ }^{2}$
}

Address: ${ }^{1}$ Department of Paediatrics and Child Health and the School of Adolescent Health, Red Cross Children's Hospital, University of Cape Town, Cape Town, South Africa and 2Department of Chemical Pathology and the School of Adolescent Health, Red Cross Children's Hospital, University of Cape Town, Cape Town, South Africa

Email: Sandra Pienaar - spienaar@ich.uct.ac.za; Brian S Eley* - beley@ich.uct.ac.za; Jane Hughes - jhughes@ich.uct.ac.za; Howard E Henderson - henders@ich.uct.ac.za

* Corresponding author

Published: 28 November 2003

BMC Pediatrics 2003, 3:12
Received: 05 September 2003

Accepted: 28 November 2003

This article is available from: http://www.biomedcentral.com/I47I-243I/3//2

(C) 2003 Pienaar et al; licensee BioMed Central Ltd. This is an Open Access article: verbatim copying and redistribution of this article are permitted in all media for any purpose, provided this notice is preserved along with the article's original URL.

\begin{abstract}
Background: The objective of this study was to describe the clinical and molecular features of the first South African family with X-linked hyper-IgM syndrome (HIGMI).

Methods: Diagnoses were based on immunoglobulin results and the absence of CD40 ligand (CD40L) expression on activated T-cells. Complete molecular characterisation involved CD40L cDNA sequencing, and genomic DNA analysis by polymerase chain reaction amplification, restriction enzyme digestion and sequencing. A PCR-based diagnostic assay was established for carrier detection and prenatal diagnosis in this family.
\end{abstract}

Results: There were originally six children, three males and three females. The eldest boy died after being diagnosed with hypogammaglobulinaemia, before HIGMI was considered. This disorder was diagnosed in the second eldest boy at the age of 5 years, after failing to detect CD40L expression on his activated T-cells. A deficiency of CD40L was also confirmed in the youngest male at the age of 5 years. Both younger brothers have since died of infections relating to HIGMI. Molecular investigation showed that exon 3 was deleted from the CD40L mRNA of the affected males. Genomic DNA analysis identified a 1.5 kilobase deletion, spanning exon 3 and including extended flanking intronic sequence. Carrier status in the mother was confirmed by RT-PCR of her CD40L mRNA. Genetic analysis of the three female children was deferred because they were below the legal consenting age of 18 years. A PCR-based assay for genomic DNA was established for easy identification of female carriers and affected males in the future.

Conclusions: This study confirmed the diagnosis of HIGMI in the first South African family to be investigated and identified a novel mutation in the CD40L gene.

\section{Background}

Immunodeficiency with hyper-IgM was first described in 1960 [1] and mapped to Xq26, in 1992, using DNA from families showing $\mathrm{X}$-linked inheritance of the condition [2]. This locus was known to contain the CD40 ligand (CD154) gene. Shortly thereafter, several groups inde- pendently showed that mutations in this gene caused the disorder, which is now known as Hyper IgM Type I (HIGM1) [3,4]. The autosomal recessive forms took longer to delineate with two defects being described in the past three years. Hyper IgM Type II (HIGM2) is caused by mutations in the activation-induced cytidine deaminase 
(AID) gene, while Type III (HIGM3) is due to defects in the gene encoding CD40 $[5,6]$.

The clinical manifestations of HIGM1 include recurrent upper and lower respiratory tract infection, interstitial pneumonia, chronic diarrhoea, oral ulcers, sclerosing cholangitis and hepatitis. Less commonly arthritis, meningoencephalitis and tumours occur $[7,8]$. Patients with HIGM1 are uniquely susceptible to interstitial pneumonia caused by Pneumocyctis carinii. Cryptosporidium parvum is frequently isolated from patients with chronic diarrhoea and ascending cholangitis. The immunodeficiency classically presents with elevated or normal IgM levels and low IgA, IgG and IgE concentrations. Neutropaenia is frequently documented. Treatment consists of prophylactic co-trimoxazole and intranvenous immunoglobulin replacement, and advice to boil water to prevent cryptosporidium infection. Granulocyte-colony stimulating factor may improve the neutropaenia. Despite optimal medical treatment prognosis is unfavourable as less than $30 \%$ survive beyond the $3^{\text {rd }}$ decade of life. Bone marrow transplantation may be curative and is being increasingly considered Patients with advanced liver disease occasionally benefit from combined liver and bone marrow transplantation $[9,10]$.

The CD40L gene comprises 5 exons, 4 introns, and spans 12 kilobases. It encodes a type II transmembrane glycoprotein of 261 amino acids, which has a molecular mass of $39 \mathrm{kDa}$ and is a member of the TNF superfamily. Domains of the protein include a short cytoplasmic tail, a transmembrane section and an extracellular region that shares homology with TNF- $\alpha$. CD40L is mainly expressed by activated CD4+ T-cells $[4,11,12]$ and is functional as a homotrimer. Other cells expressing CD40L include B cells, macrophages, monocytes, dendritic cells and endothelial cells. The interaction of CD40L on activated CD4 cells with CD40 on B-cells induces B-cell proliferation, immunoglobulin isotype switching, germinal centre formation and somatic hypermutation. Dysfunctional CD40 ligation thus prevents isotype switching from IgM, and results in the typical immunodeficiency $[12,13]$. Failure to isotype switch, as well as failure to activate Kuppfer cells and pulmonary macrophages increases the risk for Pneumocystis carinii and Cryptosporidial infection [7]. Autosomal forms of hyper-IgM syndrome are due to defects of B-cells, rather than T-cells [14].

The European CD40L defect database contains mutations scattered throughout the length of the gene. However, mutations are more common in the extracellularly located TNF-homology domain [15]. A variety of missense, nonsense, splice-site, deletion and insertion mutations have been reported $[15,16]$. In the present report we describe

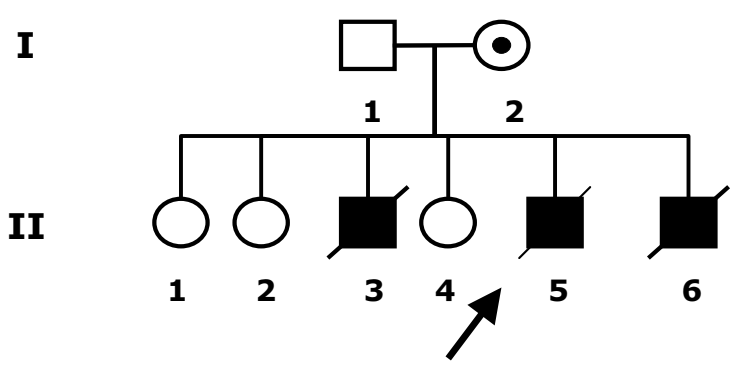

Figure I

Pedigree of the affected family.

the characterisation of a novel deletion mutation in the first South African kindred with HIGM1.

\section{Methods \\ Subjects}

The kindred is of African ancestry and included 6 children, 3 boys and 3 girls. All three boys were affected and all died during early childhood from complications relating to hyper-IgM syndrome (Figure 1). The Research Ethics Committee of the University of Cape Town approved this study. Informed consent for molecular analysis was obtained from the parents.

\section{CD40L expression}

CD40L expression on activated $\mathrm{T}$ cells was measured by flow cytometry as previously described [17].

\section{Activation of T-cells and CD40L CDNA analysis}

Peripheral blood mononuclear cells (PBMCs) $\left(10 \times 10^{6}\right)$ separated from heparinized blood by Ficoll isopaque density centrifugation, were incubated in $10 \mathrm{ml}$ RPMI-1640 cell culture medium, $12 \% \mathrm{AB}$ serum, with phorbol myristate acetate (PMA) $(10000 \mathrm{ng} / \mathrm{ml})$ and Ionomycin $(1.5$ $\mathrm{mg} / \mathrm{ml}$ ) for 6 hours, to allow for activation of the T-cells. Total RNA was isolated and the mRNA fraction converted into cDNA, from which CD40L cDNA was amplified using CD40L specific primers. The primer pair used was: 5'-CTCTGCCAGAAGATACCATTTCAAC-3' (F) and 5'TATGAAGACTCCCAGCGTCAGC-3' (R). The amplified CDNA was sequenced using the ABI BigDye sequencing method.

\section{Results \\ Clinical and laboratory data}

The clinical data of the three affected children are summarised in table 1. Neutropaenia was intermittently 
Table I: Clinical data

\begin{tabular}{|c|c|c|c|c|}
\hline Patient No. & Age at investigation & $\begin{array}{l}\text { Immunoglobulin levels } \\
\text { (initial) }\end{array}$ & CD40L status & Treatment and Outcome \\
\hline I & 10 months & $\lg M \uparrow, \lg G \downarrow, \lg A$ normal & Not done & $\begin{array}{l}\text { 4-weekly IVIG administered. Developed } \\
\text { bronchiectasis. Died at age } 17 \text { months during an } \\
\text { episode of pneumonia and acute-on-chronic } \\
\text { respiratory failure }\end{array}$ \\
\hline 2 & 24 months & IgM normal, IgG $\downarrow, \lg A \downarrow$ & CD40L deficiency & $\begin{array}{l}\text { 4-weekly IVIG and cotrimoxazole prophylaxis } \\
\text { administered. Developed cryptococcal-associated } \\
\text { ascending cholangitis / chronic liver disease. Died } \\
\text { at the age of } 7 \text { years of an unknown cause }\end{array}$ \\
\hline 3 & 9 months & $\lg M \uparrow, \lg G \downarrow, \lg A$ normal & CD40L deficiency & $\begin{array}{l}\text { I infusion of IVIG administered. Died at age } 10 \\
\text { months due to interstitial pneumonia and acute } \\
\text { respiratory failure }\end{array}$ \\
\hline
\end{tabular}

documented during the clinical course of the two younger affected males but was not documented in the eldest male. There was no CD40L expressed by the activated T cells of two of the affected boys (data not shown).

\section{Nucleic acid analysis}

CD40L cDNA was analysed in the first instance, with RTPCR yielding a PCR product from the proband (second eldest, affected male, which was approximately $60 \mathrm{bp}$ shorter than normal (Figure 2a). This was most likely indicative of a splicing deletion involving either exon 3 or 4 as they are of this magnitude. Sequencing confirmed a deletion of exon 3 (58 bp), with exon 2 correctly spliced to exon 4 (Figure 2a,2b).

Attempts to examine exon 3 splice-site sequences were unsuccessful as we were unable to amplify exon 3 from genomic DNA using close, flanking intronic PCR primers. This problem was suggestive of a large deletion incorporating exon 3 and some flanking intronic sequence. Knowing that the patient had an intact exon 2 and 4 we chose primers with sequence from the intronic regions immediately flanking these exons. We were able to amplify across these exons by using long range Taq polymerase (Expand TM High Fidelity PCR System, [Roche, Catalogue No 1732641]). This gave PCR products of $6059 \mathrm{bp}$ from a normal male and approximately 4500 bp from our patient, indicative of a deletion approximating $1500 \mathrm{bp}$. The positions of the deletion breakpoints in introns 2 and 3 were roughly determined by comparison of the restriction maps of both PCR products. Localisation of these breakpoints, allowed us to sequence across the junction site in one sequencing attempt and size the deletion at exactly $1500 \mathrm{bp}$. This site and immediate flanking sequence is given in Figure $3 \mathrm{a}$.

To facilitate carrier detection we set up a PCR assay using primers flanking the deleted region. This assay gives a PCR product of $1741 \mathrm{bp}$ from normal alleles and a product of $241 \mathrm{bp}$ from the mutant allele. This is clearly shown in Figure $3 \mathrm{~b}$ where PCR products from the patient and his carrier mother have been compared.

This deletion mutation is novel and has been submitted to the CD40L database with the following annotation: Reference sequence NT_011719, variant sequence bases 3083058-3084557 deleted [15].

\section{Discussion}

In sub-Saharan Africa the diagnosis of primary immunodeficiency diseases is constrained by limited diagnostic facilities; few African centres have reported on these conditions. This manuscript is the first South African report of a kindred with HIGM1 to be fully characterised at the clinical and molecular level. While the immunology service at Red Cross Children's Hospital has been diagnosing primary immunodeficiency diseases for more than 30 years [18] a flow cytometric assay [17] for detecting CD40 ligand expression on activated T-cells was only established in 1998, facilitating the diagnosis of HIGM1 in the index family. This development occurred after the eldest, affected boy had died.

Low IgG concentration with either a normal or increased IgM concentration was present at the initial assessment of all three patients and is a fairly consistent feature of HIGM1 [7]. However, the normal IgA concentration recorded in two of the affected males is not a usual feature, and it should not thus preclude consideration of HIGM1 in the differential diagnosis of males with hypogammaglobulinaemia. Although the second patient initially had a normal IgM concentration, 3 years later the IgM concentration was 1.5 times the normal upper limit. The elevated IgM concentration in these patients is not a genetically determined feature but rather reflects a chronic, poorly controlled primary response to the many infections that 

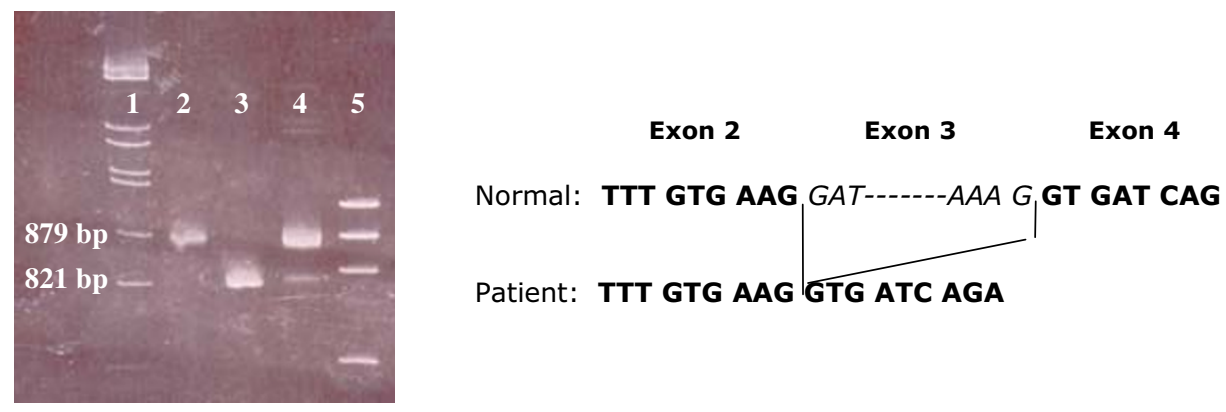

\section{Figure 2}

(a) Polyacrylamide gel electrophoresis of PCR amplified CD40L cDNA from a normal control (lane 2), the proband (II.5; lane 3 ), and his mother (lane 4), MWT markers (lanes I and 5); (b) Boundary sequences of exons 2, 3 and 4 of control and patient CD40L cDNA. The sequence for exon 3 is shown in italics.

afflict these patients [7]. Medical treatment did not prevent the early demise of the three children. Despite intravenous immunoglobulin therapy less that $30 \%$ of patients with HIGM1 live beyond the third decade as they also have an increased tendency to autoimmune disease and cancer $[8,19]$. Improved outcome of bone marrow transplantation makes this therapeutic modality increasingly attractive in treating children with HIGM1 $[9,20]$.

The deletion of exon 3 from the CD40L gene not only results in the loss of 19 amino acids from the primary sequence but also alters the reading frame of the mRNA transcript beyond the exon 2 / exon 4 coupling (Figure 2a), resulting in a premature termination codon 12 amino acid residues downstream. The final mRNA transcript is therefore shorter and carries a premature termination codon within the first third of the prescribed coding sequence. The introduction of premature stop codons in mRNA transcripts is known to often hasten their degradation in a process referred to as nonsense-mediated mRNA decay [21] and appears to be operative for this mutation. The amplification of CD40L cDNA from the carrier mother of our patient, clearly shows a marked reduction in staining intensity for the shorter and mutated transcript
(Figure 2b) and is suggestive of a large discrepancy in PBMC template concentrations of the mRNA transcripts from the two alleles she carries.

Scrutiny of the CD40L mutation database reveals that large deletions are rarely encountered in affected subjects, showing the absence of repeat unit "hotspots" sometimes recorded at other gene loci [22]. We have analysed the breakpoint and flanking sequences from our patient and find that the deletion has occurred at a short 4 bp direct repeat (GGCC), which is similar to the short direct repeats reported in deletions of the retinoblastoma gene [23].

Carrier detection in this family has only been extended to the mother of our patient where PCR confirmed her obligate carrier status (Figure $3 \mathrm{~b}$ ). This family has been counselled to delay screening of the three female siblings until they are older and are contemplating having children of their own.

In conclusion, advances in the fields of genetics, and cellular and molecular biology during the last decade have helped to clarify many aspects of the pathogenesis of the hyper IgM syndromes, and allowed us to completely char- 

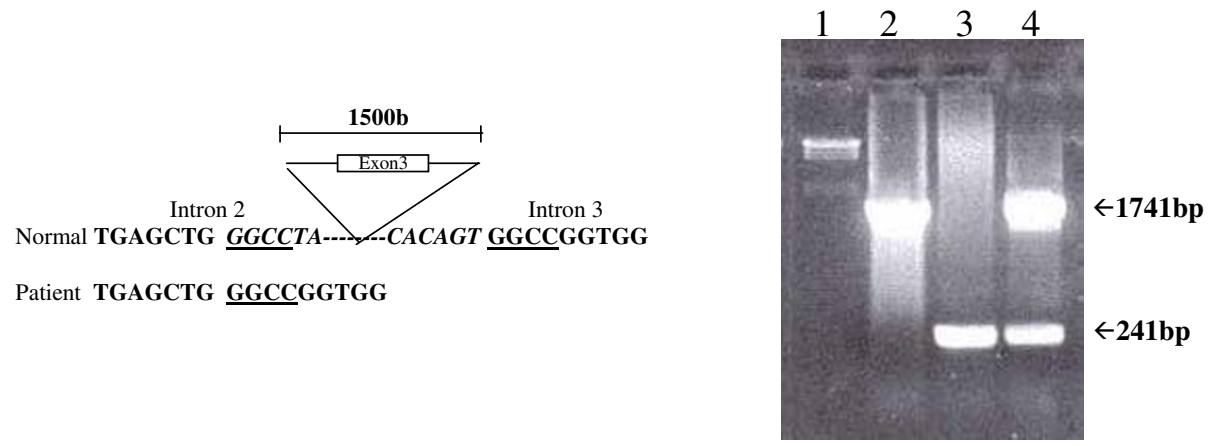

\section{Figure 3}

(a) Partial sequence across the deletion breakpoints in control DNA as compared to the sequence across the junction site in our patient (Figure I; II.5). Sequence corresponding to the beginning and end of the deleted section is given in italics. The short $4 \mathrm{bp}$ repeat at the breakpoints is underlined. (b) Agarose gel electrophoresis of PCR product spanning the I500 bp deletion: MWT marker (lane I), control DNA (lane 2), patient DNA (lane 3), maternal [carrier] DNA (lane 4).

acterise the HIGM1 mutation in this family. Recent progress should lead to a greater understanding of the spectrum of immunological and genetic disorders in subSaharan Africa.

\section{List of abbreviations}

cDNA complementary deoxyribonucleic acid

CD40L CD40 ligand

DNA deoxyribonucleic acid

HIGM1 X-linked hyper IgM syndrome or Hyper IgM Type I

HIGM2 Hyper IgM Type II

HIGM3 Hyper IgM Type III

IgA Immunoglobulin A
IgE Immunoglobulin E

IgG Immunoglobulin G

IgM Immunoglobulin M

mRNA messenger ribonucleic acid

PCR polymerase chain reaction

RT-PCR reverse transcriptase polymerase chain reaction

TNF tumor necrosis factor

TNF- $\alpha$ tumor necrosis factor- $\alpha$

PBMCs peripheral blood mononuclear cells

PMA phorbol myristate acetate 


\section{Competing interests}

None declared.

\section{Authors' contributions}

Sandra Pienaar - completed all the molecular work, and wrote the first draft

Brian Eley - managed the patients, counselled the family, wrote the clinical sections of the article and co-ordinated the final draft

Jane Hughes - established the flow cytometric assay for determining CD40L expression

Howard Henderson - directed the molecular work, assisted in the interpretation of the results and contributed significantly to the final draft

\section{Acknowledgements}

The financial support of the Institute of Child Health, the UCT research committee and the Medical Research Council is gratefully acknowledged.

\section{References}

I. Isreal-Asselain R, Burtin P, Chebat J: Un trouble biologique nouveau: L'agammaglobulinemie avec beta2-microglobulinemia (un cas). Bull Soc Med Hosp Paris 1960, 76:519-523.

2. Padayachee M, Feighery C, Finn A, McKeown C, Levinsky RJ, Kinnon $\mathrm{C}$, Malcolm S: Mapping of the X-linked form of hyper-IgM syndrome (HIGMI) to Xq26 by close linkage to HPRT. Genomics 1992, I4(2):55I-3.

3. Allen RC, Armitage RJ, Conley ME, Rosenblatt H, Jenkins NA, Copeland NG, Bedell MA, Edelhoff S, Disteche CM, Simoneaux DK, Fanslow WC, Belmont J, Spriggs MK: CD40 ligand gene defects responsible for $\mathbf{X}$-linked hyper-IgM syndrome. Science 1993, 259:990-3.

4. Aruffo A, Farrington M, Hollenbaugh D, Li X, Milatovich A, Nonoyama S, Bajorath J, Grosmaire LS, Stenkamp R, Neubauer M: The CD40 ligand gp39 is defective in activated $T$ cells from patients with X-linked hyper IgM syndrome. Cell 1993, 72:291.

5. Revy P, Muto T, Levy Y, Geissmann F, Plebani A, Sanal O, Catalan N, Forveille M, Dufourcq-Labelouse R, Gennery A, Tezcan I, Ersoy F, Kayserili H, Ugazio AG, Brousse N, Muramatsu M, Notarangelo LD, Kinoshita K, Honjo T, Fischer A, Durandy A: Activation-induced cytidine deaminase (AID) deficiency causes the autosomal recessive form of hyper-IgM syndrome (HIGM2). Cell 2000, 1 02:565-575.

6. Ferrari S, Giliani S, Insalaco A, Al-Ghonaium A, Soresina AR, Loubser M, Avanzini MA, Marconi M, Badolato R, Ugazio AG, Levy Y, Catalan N, Durandy A, Tbakhi A, Notarangelo LD, Plebani A: Mutations in CD40 gene causes an autosomal recessive form of immunodeficiency with hyper IgM. Proc Natl Acad Sci USA 2001, 98:12614-12619.

7. Levy J, Espanol-Boren T, Thomas C, Fischer A, Tovo P, Bordigoni P, Resnick I, Fasth A, Baer M, Gomez L, Sanders EA, Tabone MD, Plantaz D, Etzioni A, Monafo V, Abinun M, Hammarstrom L, Abrabamsen T, Jones A, Finn A, Klemola T, DeVries E, Sanal O, Peitsch MC, Notarangelo LD: Clinical spectrum of X-linked hyper-IgM syndrome. J Pediatr I997, I 3 I ((I pt I)):47-54.

8. Notarangelo LD, Hayward AR: X-linked immunodeficiency with hyper-IgM (XHIM). Clin Exp Immunol 2000, I 20:399-405.

9. Khawaja K, Gennery AR, Flood TJ, Abinun M, Cant AJ: Bone marrow transplantation for CD40 ligand deficiency: a single centre experience. Arch Dis Child 2001, 84:508-5II.

10. Hadžic N, Pagliuca A, Rela M, Portmann B, Jones A, Veys P, Heaton ND, Mufti G], Mieli-Vergani G: Correction of the hyper-IgM syndrome after liver and bone marrow transplantation. $N$ Engl J Med 2000, $321: 320-324$.
II. Hollenbaugh D, Wu LH, Ochs HD, Nonoyama S, Grosmaire LS, Ledbetter JA, Noelle RJ, Hill H, Aruffo A: The random inactivation of the $X$ chromosome carrying the defective gene responsible for X-Linked Hyper IgM Syndrome (XHIM) in female carriers. J Clin Invest 1994, 94:616-622.

12. Clark LB, Foy TM, Noelle RJ: CD40 and its ligand. Adv Immunol 1996, 63:43-78

13. Durie FH, Foy TM, Masters SR, Laman JD, Noelle RJ: The role of CD40 in the regulation of humoral and cell-mediated immunity. Immunol Today 1994, I 5:406-4II.

14. Conley ME, Larché M, Bonagura VR, Lawton AR 3rd, Buckley RH, Fu SM, Coustan-Smith E, Herrod HG, Campana D: Hyper IgM syndrome associated with defective CD40-mediated B cell activation. J Clin Invest 1994, 94: | 404- I409.

15. The European CD40L defect database [http://www.uta.fi/imt/ bioinfo/CD40Lbase/]

16. Notarangelo LD, Peitsch MC: CD40Lbase: A database of CD40 $L$ gene mutations causing $X$-linked hyper-IgM syndrome. Immunol Today 1996, 17:511-516.

17. O'Gorman MRG, Zaas D, Paniagua M, Corrochano V, Scholl PR, Pachman LM: Development of a rapid whole blood flow cytometry procedure for the diagnosis of $X$-linked hyper-IgM syndrome patients and carriers. Clin Immunol Immunopathol 1997, 85: $\mid 72-181$.

18. Eley B, Beatty D: Primary immunodeficiency diseases in Cape Town. Allergy \& Clinical Immunology International 2000, I 2:267-270.

19. Arkwright PD, Abinun M, Cant AJ: Autoimmunity in human primary immunodeficiency diseases. Blood 2002, 99:2694-2702.

20. Antione C, Muller S, Cant A, Cavazzana-Calvo M, Veys P, Vossen J, Fasth A, Heilmann C, Wulffraat N, Seger R, Blanche S, Friedrich W, Abinun M, Davies G, Bredius R, Schulz A, Landais P, Fischer A, European Group for Blood and Marrow Transplantation; European Society for Immunodeficiency: Long-term survival and transplantation of haemopoietic stem cells for immunodeficiencies report of the European experience I 968 - 99. Lancet 2003, 36 I:553-560.

21. Buhler M, Wilkinson MF, Muhlemann O: Intranuclear degradation of nonsense codon-containing mRNA. EMBO Rep 2002, 3:646-5I.

22. Rudiger NS, Gregersen N, Kielland-Brandt MC: One short well conserved region of Alu-sequences is involved in human gene rearrangements and has homology with prokaryotic chi. Nucleic Acids Res 1995, 23:256-60.

23. Canning S, Dryja TP: Short direct repeats at the breakpoints of deletions of the retinoblastoma gene. Proc Natl Acad Sci USA 1989, 86:5044-48.

\section{Pre-publication history}

The pre-publication history for this paper can be accessed here:

http://www.biomedcentral.com/1471-2431/3/12/prepub

Publish with Bio Med Central and every scientist can read your work free of charge

"BioMed Central will be the most significant development for disseminating the results of biomedical research in our lifetime. "

Sir Paul Nurse, Cancer Research UK

Your research papers will be:

- available free of charge to the entire biomedical community

- peer reviewed and published immediately upon acceptance

- cited in PubMed and archived on PubMed Central

- yours - you keep the copyright 